\title{
IMPROVING PASTURE BY WINTER MANAGEMENT
}

\author{
B. W. Parker and B. H. Willis \\ Farm Advisory Officers, New Plymouth
}

DuRING the last few seasons many dairy farmers in Taranaki have noted that winter-grazed paddocks have grown more feed, and of a better quality, than paddocks-not grazed in the winter. These farmers were part of the high proportion which has adopted the winter grazing system commonly known as "block" or "long rotation" wintering.

The wide adoption of block wintering has involved a marked swing away from systems dependent on cropping, silage and autumn-saved pasture to one more dependent on winter-grown grass, using as little hay as possible.

Block wintering has some features in common with the autumnsaved pasture method evaluated by McKenzie (1961) but many of the disadvantages have been eliminated. In its present form block wintering involves the grazing of 70 to $80 \%$ and sometimes $100 \%$ of the farm's grazable area by the herd from late May to early August. Cows and in-calf heifers are confined between electric wires in one or sometimes two mobs and-rotated very slowly around the farm. A fresh break of late autumn and winter grown grass is fed daily, the grass being grazed at stocking inrensities which seldom. fall below 300 cows/ha/day and can, at times, be as high as 750 cows/ha/day. Usually the break of grass is supplemented with hay fed at a level dependent on the amount of grass available on the block.

The main advantage of the system is the marked flexibility and ease it gives to management. Also important is the relatively stable, high, and controllable level of nutrition. However, the effect on the composition and rate of growth of the pastures is a very important additional advantage. It is the writers' opinion that this technique of winter management has, over the last six years in Taranaki, proved to be the greatest single management. factor contributing towards pasture improvement. The remainder of this paper will examine this pasture-improvement aspect.

Yorkshire fog and Agrostis species (browntop and creeping bent) grow strongly in the Taranaki pasture environment, with its

light, free-draining, difficult-to-consolidate, andesitic 'ash soils and 
high rainfall. These species are considered undesirable either because of their unsuitable seasonal growth pattern, their low nutritive value, or their ability to form dense associations which inhibit clover growth. These grasses were allowed to dominate by the wintering systems commonly used in the past. The practice of leaving a large proportion of the farm closed for the whole winter encourages Yorkshire fog dominance. The close and continuous grazing of the "split herd" or "multiple mob" system (McKenzie, 1961), which was popular in the early 1960s, encourages the mat-like Agrostis species.

In contrast to these other systems, block wintering encourages the more desirable species: Ruanui and Manawa ryegrasses, cocksfoot and white clover. The writers believe that this is brought about by a combination of the three factors of which the first is the most important:

(1)' The intensive but brief treading effect.

(2) The quick, hard grazing followed by a long rest spell.

(3) The concentration of dung and urine deposited on each break.

Research at the Grasslands Division, DSIR, showed Ruanui ryegrass to be more resistant to treading than other grasses found in New Zealand pastures (Edmond, 1963).

Observations of block wintering by many advisers support Edmond's finding. In the growing season immediately following the block wintering of a pasture, the ryegrass content of the pasture has always increased, sometimes dramatically, when compared with similar pastures nearby which had not been treated in this way.

Further support can be seen in the extreme dominance of ryegrasses often seen in the much-used paths of vehicles across paddocks. These areas are not affected by the dung and urine concentrations which probably play an important part in the development of the same dominance around troughs and gateways.

The treading in block wintering appears to decrease markedly the competitive ability of the undesirable species. Ryegrasses have the ability to take advantage of this through not having been so severely damaged and also because of their high winter growth potential. The proportion of white clover in the sward is also observed to increase with block wintering. It is suggested that this arises simply. from the reduction in competitive ability of the mat-forming Yorkshire fog and Agrostis species. 
Block grazing has been criticized on the grounds that both undesirable and desirable species are damaged by treading and total pasture production in the long term will suffer. This contention may well hold for soil types which are susceptible to poaching or in pastures dominant in desirable species. However, on Taranaki's free-draining, volcanic ash soils with their mixed pastures, the undesirable effects of treading appear to be more than compensated for by the improved composition of the sward. Pugging or poaching, as defined by breaking of the soil surface through treading, occurs to only a limited extent and only where very high stocking rates are associated with heavy rainfall. The treading effects of about 350 to 500 cows per hectare per day in normal weather conditions appear to be mainly beneficial. Severe poaching necessitating oversowing is estimated to occur, on average, on no more than $1 \%$ of the block wintered area.

It has been argued that the effect of the severe pasture defoliation, which occurs with block grazing, is to depress pasture yield by lowering plant density and photosynthetic activity. This is undoubtedly true, but while the defoliation may be severe it occurs only once a year and only in the winter.

Brougham (1960) showed that, while severe defoliation in winter can depress' pasture yield, this effect is only minimal compared with severe defoliation in the summer. After block winter grazing initial regrowth may be slow, but, when ryegrasses and clover take over from the more undesirable low producing species and make better use of the available light, the pasture growth after the 70 to 90 day spell will be greater than that of a winterspelled pasture.

Rotation lengths for block grazing on Taranaki dairy farms at present are approximately 70 to 90 days at grazing intensities of about 350 to $500 \mathrm{cows} / \mathrm{ha} /$ day. The resulting improvement in the sward, particularly in the first two seasons, and the better winter growth should allow the use of a shorter rotation with lower grazing intensity and less severe defoliation, The shorter spells should allow the density of the pasture to increase, thus improving the light interception of the sward.

An increasing awareness of the benefits of late winter and early spring dressing of nitrogen fertilizers should also increase farmer confidence to speed up their winter grazing rotations.

The grazing management techniques described in this paper are, in the opinion of the writers, the most important in pasture improvement on the volcanic soils of Taranaki. 